\title{
Urban Spatial Risk Assessment of Fire from Fueling Stations on Buildings Case Study: Lubaga Division, Kampala City, Uganda
}

\author{
Ismail Wadembere, Joan Apaco* \\ Department of Lands and Architectural Studies, Faculty of Engineering, Kyambogo University, Kampala, Uganda \\ Email: ‘joanapaco01@gmail.com
}

How to cite this paper: Wadembere, I. and Apaco, J. (2020) Urban Spatial Risk Assessment of Fire from Fueling Stations on Buildings Case Study: Lubaga Division, Kampala City, Uganda. Journal of Building Construction and Planning Research, 8 , $57-72$.

https://doi.org/10.4236/jbcprt.2020.81005

Received: July 22, 2019

Accepted: March 28, 2020

Published: March 31, 2020

Copyright $\odot 2020$ by author(s) and Scientific Research Publishing Inc. This work is licensed under the Creative Commons Attribution International License (CC BY 4.0).

http://creativecommons.org/licenses/by/4.0/ (c) (i) Open Access

\begin{abstract}
The discovery of oil and gas in Uganda has attracted many investors, leading to increase in fuel/gas distributing companies and fueling stations creating rapid demand for land to locate the stations compared to available open urban land. Because of the explosive and combustion characteristics of fuel stored and dispensed at stations, several studies have been conducted on different fires at fueling stations such as static fire, jet fire, vapor cloud explosions, open fires, etc. but there was need to assess spatially the risk of fire from stations, its consequences and sovereignty on buildings surrounding them. This was done basing on seven parameters-proximity of buildings to stations, building materials, distance between buildings, wind speed, temperature, slope and vegetation. Analytical hierarchy process and pairwise comparison were used to weight the parameters based on their relative importance. Weighted sum tool was applied to generate the fire risk maps for the quarters-December to February, March to May, June to August, and September to November from 2008 to 2013. The parameters were overlaid with the buildings in each risk zone for all the four quarters and their influences determined. The highest contributors were proximity of the buildings to stations, building materials and separation between buildings. Most of the affected buildings were made of rusted corrugated iron sheets and wood; the separation distance from one building to another ranged from $0-4 \mathrm{~m}$. Most of buildings located within $100 \mathrm{~m}$ from stations were at moderate risk level and within $50 \mathrm{~m}$ were at highest risk level. The period of December to February and June to August had the highest risk. The findings can be used to guide planners and policy makers on building location vs. material vs. separation. It can also guide developers on where, when and how to carry out their developments.
\end{abstract}

\section{Keywords}

Fire Risk, Fuel Stations, Buildings and Spatial Analysis 


\section{Introduction}

East Africa's oil and gas sector is increasingly becoming the focus of many investors. By 2012, over 2.5 billion barrels of crude oil had been discovered in Uganda's Albertine region [1]. Uganda's emerging oil and gas industry is creating new opportunities as anticipated even though the oil and gas industry is still in its infancy. Many downstream distribution channels are springing up and one of the main offshoots of the industry is the emergence of fueling stations. Uganda had only six fuel distributing companies in 1994 [2] - Total, Shell, GAPCO, Caltex, UPET and AGIP, but currently there are more than 30 companies. Considering the high risks and dangers associated with oil; its exploration, transportation, offloading, storing, sale points and facilities should be taken with a lot of care. Currently there is a fast growth in urban areas from small market centers to megacities thus the increase in development increases the potentiality of fire occurrences due to interactions among different activities.

Fire and explosions are the major hazards caused by locating fuel stations in urban areas due to explosive and combustible characteristics of fuels stored and dispensed at fueling stations as fires inflict direct material damages to buildings [3]. It has been suggested that dense construction and more closely built structures are issues to be looked at regarding the rate of fire spread [4]. However, several studies have concentrated on different fires at fueling stations, for example static electricity, jet fires, vapor cloud explosions, open fires, electrical sparks etc. Studies on static electricity fire at fuel stations [5] as being caused by friction between the person's body and the seat during refueling which leads to the person and the vehicle to be electrically charged have been done. It is suggested that during refueling the following should be done: switch off the engine when refueling, do not smoke, do not get in and out of your car when refueling as discharge static build-up, do not use any object to jam the refueling trigger on the nozzle in order to keep it open. A study on the different fires at fuel stations [6] stated the following as sources of fuel station fires static electricity, open fire, thunder strike, high temperature, impact friction, and electrical sparks. He suggested that, the stations must be equipped with firewater systems, firefighting equipment should be well configured and refueling technology and facilities should be of good quality and well laid in appropriate manner. According to [7], fuel station fires are caused by loss of control of vehicles that hit fuel station equipment, presence of cigarette in the vicinity of fuel stations, welding activities in fuel stations, repair work on pipes connected to underground tanks being ignited by spark from an electrical tool, multiple accessory defects such as nozzle loosening, breakage in the distribution hose, porosity of pump points, joint defects, etc. lead to leaks which are initiating factors for fire outbreak due to flammability and volatility of the fuels. However, the studies do not show spatially the risk and consequences of fire on the neighboring buildings.

Fire risk is known to fuel station workers [8] as being catastrophic and suggested that fire risk information and guidelines should be formulated and disse- 
minated to workers before they agree to work at fuel stations as a hazardous premise. They also stated that, there is need for more studies assessing spatially the risk of fire from fuel stations, their consequences and sovereignty on buildings surrounding them. Thus, there is a need for this study to assess spatially the risk of fire from fuel stations on buildings which was achieved by determining parameters for assessing spatially the risk of fire from fuel stations, spatially quantifying the buildings at risk in different risk levels and determining the influence of parameters in each risk level/zone. Seven parameters-proximity of buildings to stations, building materials, distance between buildings, wind speed, temperature, slope and vegetation were identified. The study also suggested measures which can be put in place to guide planners and policy makers on building location vs. material vs. separation vs. fuel station locations. It can also guide developers on where, when and how to carry out their developments in areas neighboring fueling stations.

\section{Literature Review}

Risk [9] is the outcome of interaction between hazard phenomenon and the elements at risk (people, buildings and infrastructures) within the community. Fire risk is defined [10] as "the possibility of an unwanted fire hazard in an uncertain situation, where loss or harm may be induced to the valued, typically life, property, business continuity, heritage, and/or environment". Fire risk at fueling/gas stations is caused by electric spark, static electricity, high temperatures, open fire, smoking, thunder strikes, welding, impact friction, and many others [11]. In addition, improper operation or behavior e.g. fault operation, ignorance and facilities failure are also important factors of fire hazard. For instance, the potential failure of fire systems will significantly contribute to fire hazard in case of fire [12]. To reduce fire risk at fueling stations, several considerations include well configuration of firefighting equipment, good quality of refueling facilities and the manner in which they are laid should be appropriate, the seating of the fuel station [6]. Natural factors that influence the rate of fire spread include the following; topography (slope, aspect and elevation), climate (air temperature, relative humidity, rainfall, changes in direction and velocity of urban wind), vegetation, etc. [13]. The artificial factors include separation distance between buildings, distance to hazardous materials, building materials, etc.

Studies [9] have defined risk $=$ Hazard $\times$ Elements at Risk $\times$ Vulnerability. Hazard refers to a phenomenon or human activity that may cause property damage, social and economic disruption, loss of life or injury, or environmental degradation. Vulnerability refers to the degree of loss resulting from the occurrence of a phenomenon. Elements at risk refer to the population, properties, economic activities, including public services, or any other defined values exposed to hazards in a given area. According to [14], risk assessment is the process of estimating the impact the hazard would have on the people, structures and facilities in a community. Fire risk assessment is a management tool, which 
helps the managers in their decision-making process. Fire risk assessment is considered the foundation of fire safety measures of all buildings in use. In order to create a risk map, qualitative hazard map is generated by combining several factor maps. A vulnerability map is then created. A combination of vulnerability map and hazard map is called a risk map.

As per [10] definition of fire risk; use of suitable construction materials is one of the means of reducing fire risk [15]. The characteristics of building materials in relation to fire are: -Stone is a bad conductor of heat. Sand stones with fire grains have moderate fire resistance. Granite disintegrates under fire. Limestone crumbles easily. Bricks resist heat up to $1200^{\circ} \mathrm{C}$. At the time of construction, if good quality mortar is used, fire resistance is extremely good. Any structure made of timbers can be rapidly destroyed by fire. Concrete is a very good fire resistance. Steel bars lose tensile strength. Steel columns become unsafe during fire. Aluminum is a good conductor of heat. It has higher resistance to fire. Asbestos Cement is non-combustible material as it possesses high fire resistance.

To reduce fire risk at fuel stations, the following should be considered; well configuration of firefighting equipment, good quality of refueling facilities and the manner in which they are laid should be appropriate, the seating of the fuel station, [6]. Several studies on fire hazards and explosions at fuel storage facilities have been carried include [16], who noticed that fire and vapor clouds explosions are because of spillage of flammable liquids or fuels materials from above ground storage tanks. The factors responsible for the spillage include overfilling, leaking from worn out and corroded containment, loss of containment due to pipeline raptures etc. Vapor cloud explosions are catastrophic and destructive since the vapors released can disperse to other locations and any contact with ignition source, leads to a major explosion followed by a large fire. According to [17], the parameters used in their study of fire risk in fuel stations included; distance from the nearest fire station, automatic fire extinguishing systems, existence-extinguishing valve close to the gas stations, suitability of manual firefighting systems, the location of the stations, the state of earth system and fuel tanks. In the case of fire detection, parameters such as alarm systems, suitability of alarming systems, monitoring systems for testing concentration of inflammable materials linking of the filling station to the fire brigades via intranet were considered.

\section{Materials and Methods}

To assess the spatial risk of fire, seven parameters were considered-proximity of buildings to fuel stations, building materials, separation distances between buildings, wind speed, temperature, slope and vegetation. Pairwise comparison and analytic hierarchy process were used to rank the seven parameters chosen. The study was tested on data set from Lubaga division, Kampala City in Uganda (see Figure 1).

ASTER DEM 30 by $30 \mathrm{~m}$ resolution was acquired from USGS. Data for wind 


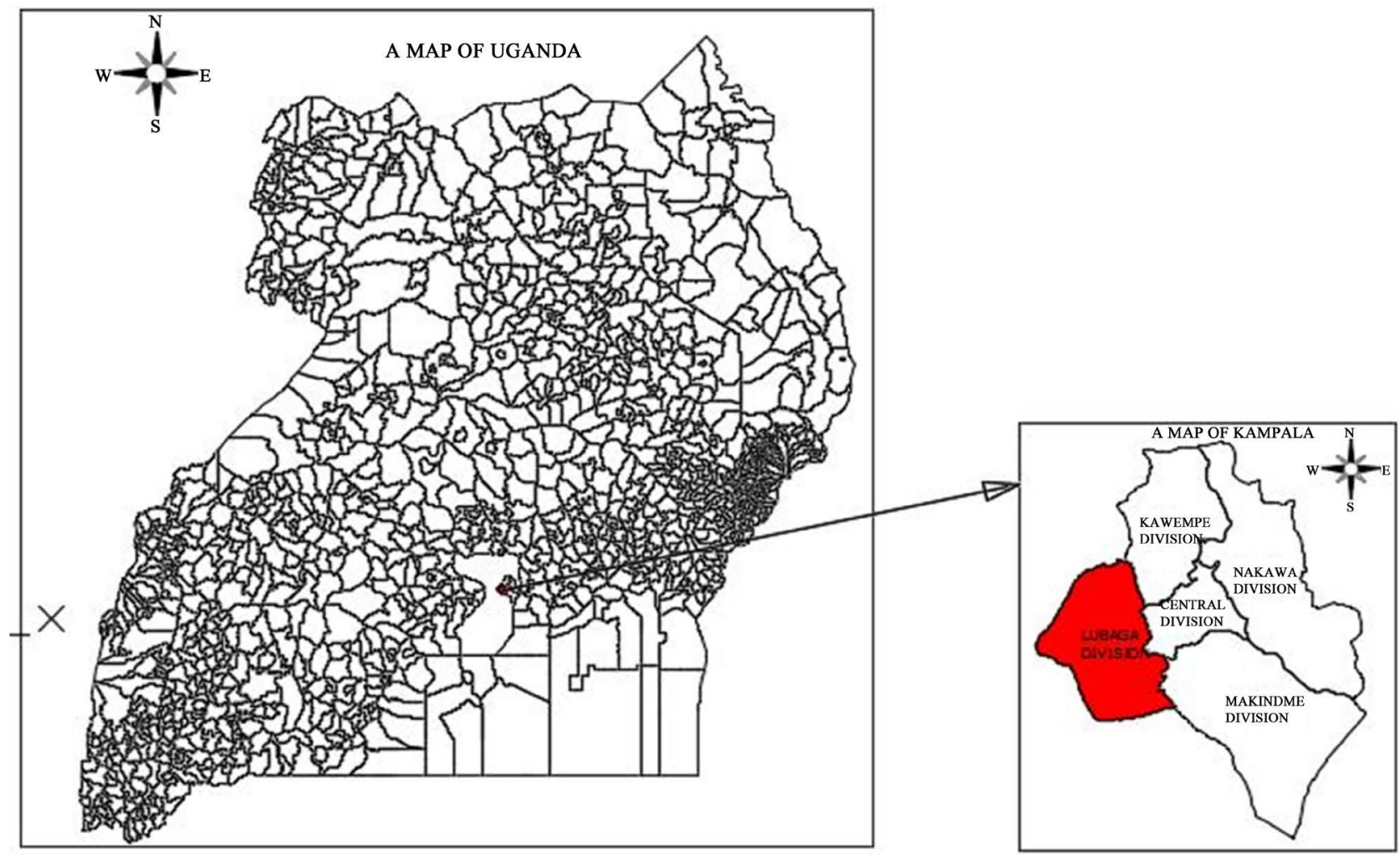

Figure 1. Location of Lubaga division in Kampala City, Uganda.

speed and temperature for the period of 2008 to 2013 was downloaded from global weather website. The data for building materials was collected from ground field survey and included roofing types; rusted corrugated iron sheets and wood, non-rusted corrugated iron sheets and wood, tiles and wood, tiles and metal, concrete roof. The geo-referenced building polygons were obtained from open street map. Fuel station positions were obtained using handheld GPS. Vegetation data was generated from Landsat 7 imagery. Then reclassification was carried that involved ranking the different classes in each dataset basing on their degree of contribution to fire risk. A linear function was used to assign preference value from 1 to 10 for each set of sub_criteria for every parameter with 10 being the most favorable or has greatest influence. The weighted sum tool in spatial analyst was used to generate the fire risk maps. The weights were generated using pairwise comparison and analytical hierarchy process was applied.

To come up with the number of buildings in each risk zone, the resultant weighted sum raster was reclassified based on its values. The reclassified raster was converted into polygons to enable vector-based GIS analysis. The polygons were then put in different categories as grid code. These categories included very high (5), high (4), moderate (3), low (2) and very low (1). Using select by attribute, a particular polygon e.g. very high was selected. Select by location was used to select buildings which were intersecting the highlighted polygons. Later the buildings were exported and saved as very high. This was done also for the other four categories. There existed a situation where some buildings were fall- 
ing in two zones (e.g. one side in very high and the other side in high). To handle such a case, that building was taken to be in the zone above the other. Since the tool selected the buildings in different zones, the join and relate tool was used to eliminate the repeated buildings. Buildings in very high zone were joined to buildings in high zone. The layer high zone was then queried to identify those buildings which were already in very high zone and were deleted from the attribute table of high zone. This was done with all the other zones. The above procedure was carried out for all the four quarters for the different years. Having quantified the buildings in different risk levels, the different layers of risk levels/zones i.e. very high, high, moderate, low and very low were then overlaid with each parameter and the influences of parameters determined.

\section{Results and Discussion}

The seven parameters used were grouped into two: human controlled (artificial) parameters and natural parameters: -Artificial parameters included; proximity of buildings to fuel stations, building materials and separation distance between buildings. These are features that human beings can easily deal with when it comes to fire risks. Natural parameters included wind speed, temperature, slope and vegetation. These are parameters that their occurrences and changes are unpredictable. Since the effect of natural parameters on fire spread depends on the human controlled parameters, if the human controlled parameters are taken care of then the natural parameters will have little influence on fire spread.

The buildings at risk were quantified according to five risk levels. The artificial parameters were used to describe the different fire risk levels as follows.

- Very high-risk level: This zone consists of buildings located $0-2 \mathrm{~m}$ from each other, within $0-100 \mathrm{~m}$ from fuel stations and majority having rusted corrugated iron sheets on wood.

- High risk level: This zone consists of the majority of the buildings with rusted corrugated iron sheets on wood, located $0-4 \mathrm{~m}$ from each other and within $50-250 \mathrm{~m}$ from fuel stations.

- Moderate risk level: The zone consists of few buildings located $0-100 \mathrm{~m}$ from fuel stations with the majority located at $150-500 \mathrm{~m}$ from fuel stations. Very few buildings consisted of rusted corrugated iron sheets on wood. With the majority made of concrete roofs and tiles on wood. Majority of reinforced concrete roof buildings located at a distance of $0-2 \mathrm{~m}$ with some few at $4-8$ $\mathrm{m}$ from other buildings, tiles on wood at $2-4 \mathrm{~m}$ from other buildings, and rusted iron sheets on wood at $4-8 \mathrm{~m}$ from other buildings.

- Low risk level: This zone consists of buildings located $300-500 \mathrm{~m}$ from fuel stations, the majority of the buildings are $6-10 \mathrm{~m}$ from each other with a few at 2 - $6 \mathrm{~m}$ from each other. Buildings are made of concrete roofs.

- Very low risk level: This zone consists of buildings located more than $500 \mathrm{~m}$ from the fuel stations with a separation distance $4 \mathrm{~m}$ and above between buildings. Buildings are made of tiles on wood, non-rusted corrugated iron sheets on wood, with some few rusted corrugated iron sheets on wood. 
The weights were generated using pairwise comparison and analytical hierarchy process, the consistency of the weights was tested and found to be within the acceptable range. $\mathrm{CR}=\mathrm{CI} / \mathrm{RCI}, \mathrm{CR}=0.1012325 / 1.32, \mathrm{CR}=0.077$. Using approach by [18], Table 1 was then drawn showing the influence of different parameters [19].

The value of CR was compared to 0.1 which is the maximum CR value for acceptable pairwise comparison [20]. The CR value was 0.077 which is within the acceptable range. Hence the weights of the above parameters reflect on their relative importance as far as fire spread is concerned. Proximity of fuel stations to buildings had the highest weight since fuel stations in this case were taken as the origin of fire outbreak. It was then followed by building materials. This is because if a building is made of fire-resistant materials however much it is close to the fuel stations it will take a longer time to be ignited. The building materials determine what distance should be between buildings that is why the separation distance between buildings to another was weighted following the building materials. Of the natural parameters, wind speed had the highest weight followed by temperature and slope (see Table 2).

The weighted seven parameters were used to generate the risk levels for all the buildings in study area as presented in Table 3.

The number of buildings in the different quarters in Table 3 were generated using GIS to show their spatial distribution (Figures 2-5) and chart (Figure 6).

From Figure 2, the majority of the buildings were either at very high risk (red) or high risk (yellow) in the months of December to February and only a few buildings were at low risk (blue) and very low risk (green) especially in the north-western part of the study area.

From Figure 3, the majority of the buildings were at high risk (yellow) in the months of March to May followed by very high risk (red) and moderate (brown) that were distributed throughout the study area.

From Figure 4, the majority of the buildings were at high risk (yellow) in the months of June to August followed by very high risk (red) mainly in central part of the study area.

From Figure 5, the majority of the buildings were at high risk (yellow) in the

Table 1. Shows criteria identifier and weight.

\begin{tabular}{ccc}
\hline Criteria No & Criteria & Weight \\
\hline C1 & Proximity of buildings to fuel stations & 0.309 \\
C2 & Building materials & 0.237 \\
C3 & Separation distance between buildings & 0.174 \\
C4 & Wind speed & 0.122 \\
C5 & Temperature & 0.080 \\
C6 & Slope & 0.049 \\
C7 & Vegetation & 0.029 \\
\hline
\end{tabular}


Table 2. Shows the influence of parameters in different risk levels.

\begin{tabular}{|c|c|c|c|c|c|}
\hline \multirow{2}{*}{$\begin{array}{l}\text { Risk assessment } \\
\text { parameters }\end{array}$} & \multicolumn{5}{|c|}{ Influence of Parameters in different Risk Levels } \\
\hline & Very high & High & Moderate & Low & Very low \\
\hline $\begin{array}{l}\text { Proximity of buildings } \\
\text { to fuel stations }\end{array}$ & $0-100 \mathrm{~m}$ & $50-250 \mathrm{~m}$ & $\begin{array}{l}\text { Few buildings at } 0-100 \mathrm{~m} \\
\text { with majority at } 150-500 \mathrm{~m}\end{array}$ & $300-500 \mathrm{~m}$ & $500 \mathrm{~m}$ \\
\hline Building materials & $\begin{array}{l}\text { Majority with } \\
\text { non-rusted corrugated } \\
\text { iron sheets on wood, } \\
\text { rusted corrugated iron } \\
\text { sheets on wood }\end{array}$ & $\begin{array}{l}\text { Majority with rusted } \\
\text { iron sheets on wood, } \\
\text { few non-rusted iron } \\
\text { sheets on wood. }\end{array}$ & $\begin{array}{l}\text { Few rusted corrugated iron } \\
\text { sheets on wood. The rest } \\
\text { reinforced concrete slab and } \\
\text { tiles on wood }\end{array}$ & Reinforced concrete & $\begin{array}{l}\text { Majority with tiles on } \\
\text { wood, reinforced } \\
\text { concrete. } \\
\text { Few rusted iron } \\
\text { sheets. }\end{array}$ \\
\hline $\begin{array}{l}\text { Separation distance } \\
\text { between buildings }\end{array}$ & $0-2 \mathrm{~m}$ & $0-4 \mathrm{~m}$ & $\begin{array}{l}\text { Majority of reinforced } \\
\text { concrete slab buildings } 0 \text { - } 2 \\
\mathrm{~m} \text { with } 4 \text { - } 8 \mathrm{~m} \text { separation } \\
\text { from each other, tiles on } \\
\text { wood } 2 \text { - } 4 \mathrm{~m} \text { and rusted iron } \\
\text { sheets on wood at } 4-8 \mathrm{~m}\end{array}$ & $\begin{array}{l}\text { Majority } 6-10 \mathrm{~m} \\
\text { With some few at } 2-6 \\
\mathrm{~m}\end{array}$ & $\begin{array}{l}\text { Majority at a distance } \\
\text { of } 4 \mathrm{~m}\end{array}$ \\
\hline $\begin{array}{l}\text { Wind speed and } \\
\text { temperature }\end{array}$ & $\begin{array}{l}\text { Dec-Feb and Jun-Aug } \\
\text { had most buildings. }\end{array}$ & $\begin{array}{l}\text { March-May and Sep } \\
\text { Nov had many } \\
\text { buildings. }\end{array}$ & $\begin{array}{l}\text { March-May, Jun-August, } \\
\text { Sep-Nov had most buildings. } \\
\text { Dec-Feb had the least }\end{array}$ & $\begin{array}{l}\text { March-May, } \\
\text { Jun-august, Sep-Nov } \\
\text { had many buildings. } \\
\text { Dec-Feb had the least. }\end{array}$ & $\begin{array}{l}\text { Almost equal } \\
\text { number of buildings } \\
\text { in all quarters. }\end{array}$ \\
\hline Slope & $0^{\circ}-5^{\circ}$ and $30^{\circ}-60^{\circ}$ & $0^{\circ}-20^{\circ}$ & $0^{\circ}-30^{\circ}$ & $0-20$ & $0^{\circ}-20^{\circ}$ \\
\hline Vegetation & Minimal & Minimal & Minimal & Minimal & Minimal \\
\hline
\end{tabular}

Table 3. Number of buildings in different risk levels for the different periods.

\begin{tabular}{ccccc}
\hline \multirow{2}{*}{ Risk levels } & \multicolumn{4}{c}{ Number of Buildings } \\
\cline { 2 - 5 } & Dec-Feb & March-May & June-Aug & Sept-Nov \\
\hline Very High & 755 & 413 & 500 & 402 \\
High & 777 & 843 & 804 & 876 \\
Moderate & 313 & 549 & 518 & 535 \\
Low & 94 & 130 & 114 & 122 \\
Very Low & 115 & 119 & 118 & 119 \\
\hline
\end{tabular}

months of September to November followed by very high risk (red) that were distributed throughout the study area.

From the above table, maps and chart, the quarter of December to February had the highest number of buildings in very high-risk zone followed by June to August. March to May and September to November had almost the same number of buildings. Basing on those findings and literature, the derivation of distances for new developments basing on the influence of parameters in different risk levels were obtained as summaries in Table 4.

The above distances were suggested for the different kinds of building roofing materials. This gives guidance when constructing a new structure, what distance should it be from the neighboring structures to reduce on the fire spread from building to another. For buildings in a hilly terrain, the separation distance from one building to another may not be constant and we suggested that in addition 


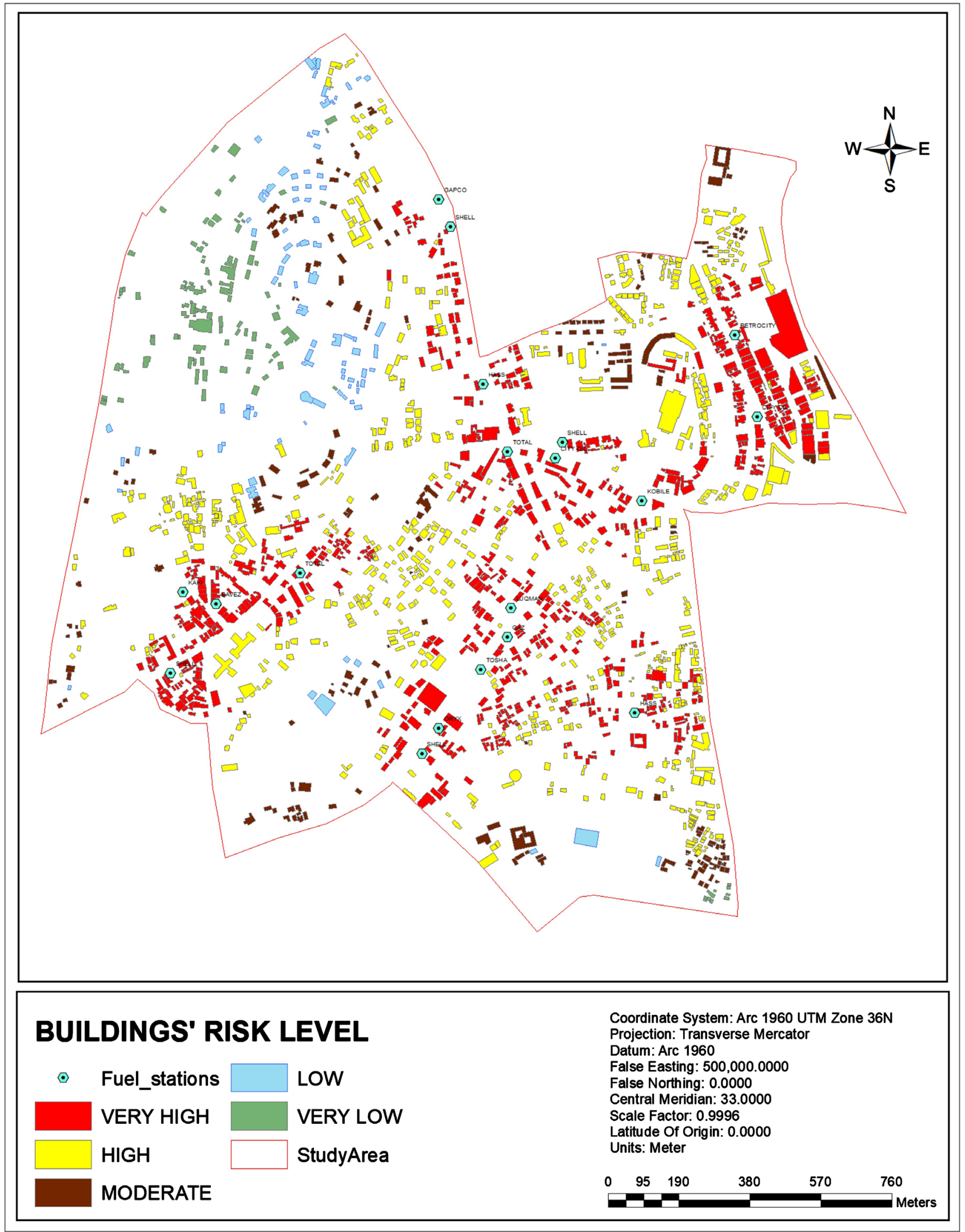

Figure 2. Fire risk map for months of December to February. 


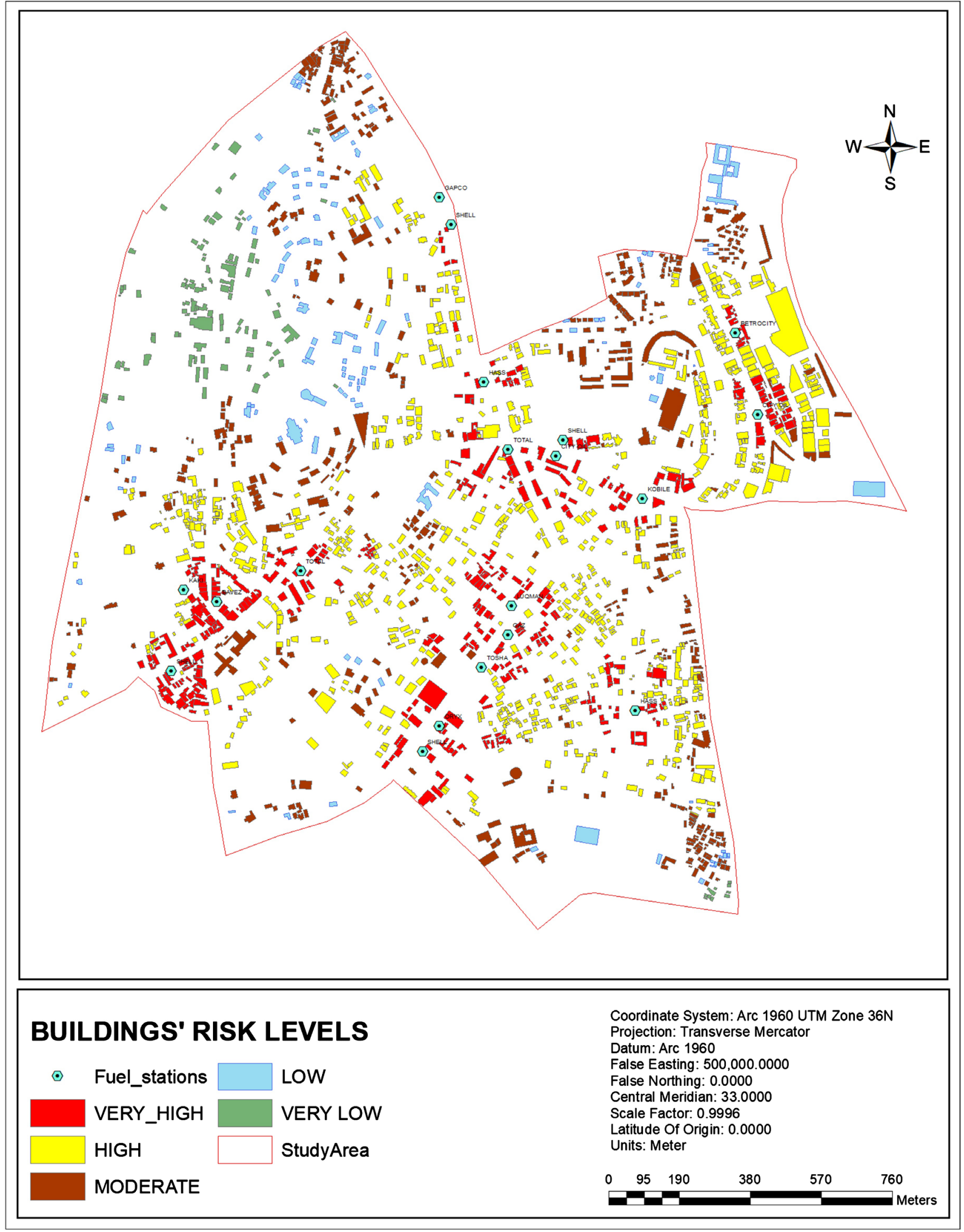

Figure 3. Fire risk map for the months of March to May. 


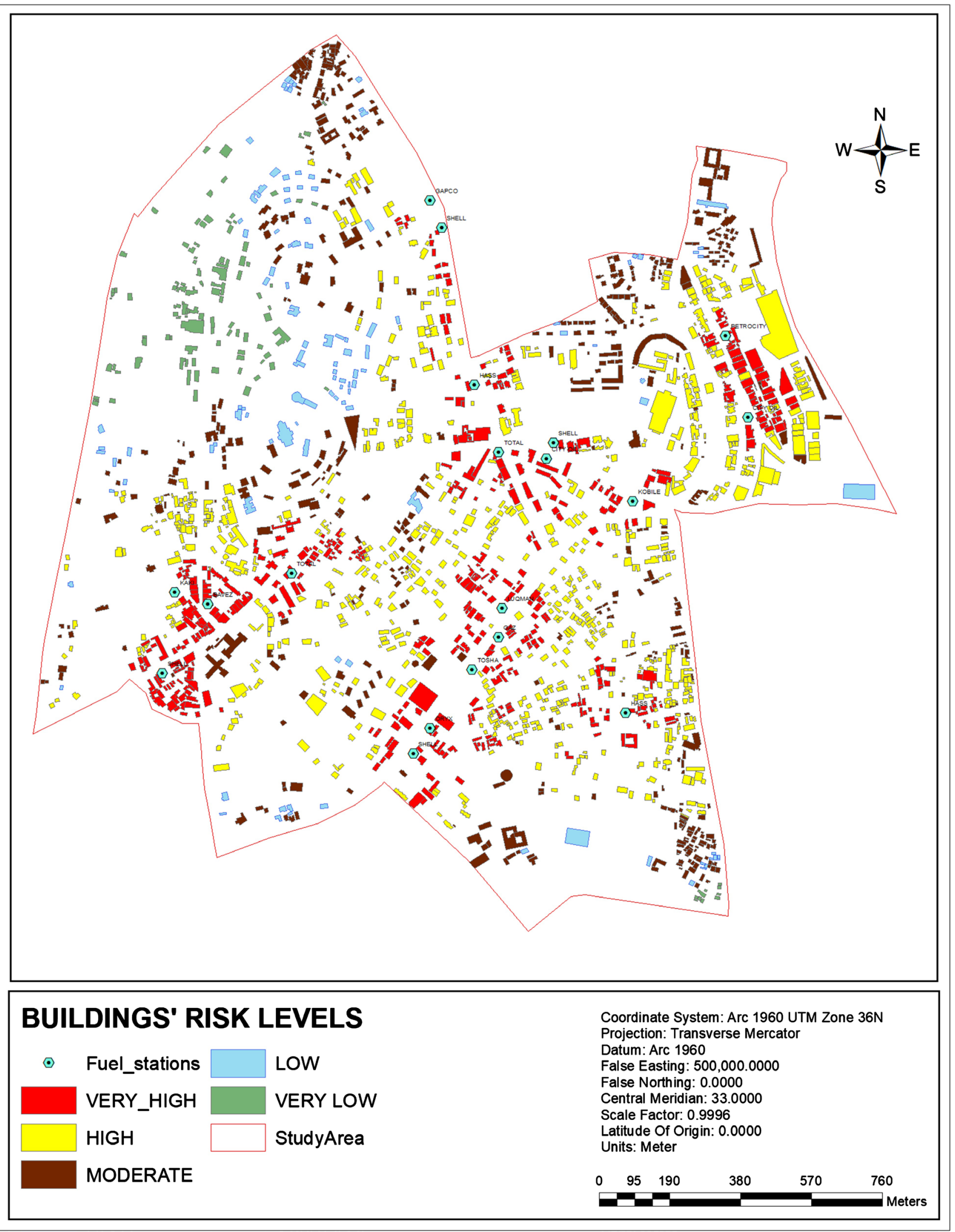

Figure 4. Fire risk map for the months June to August. 


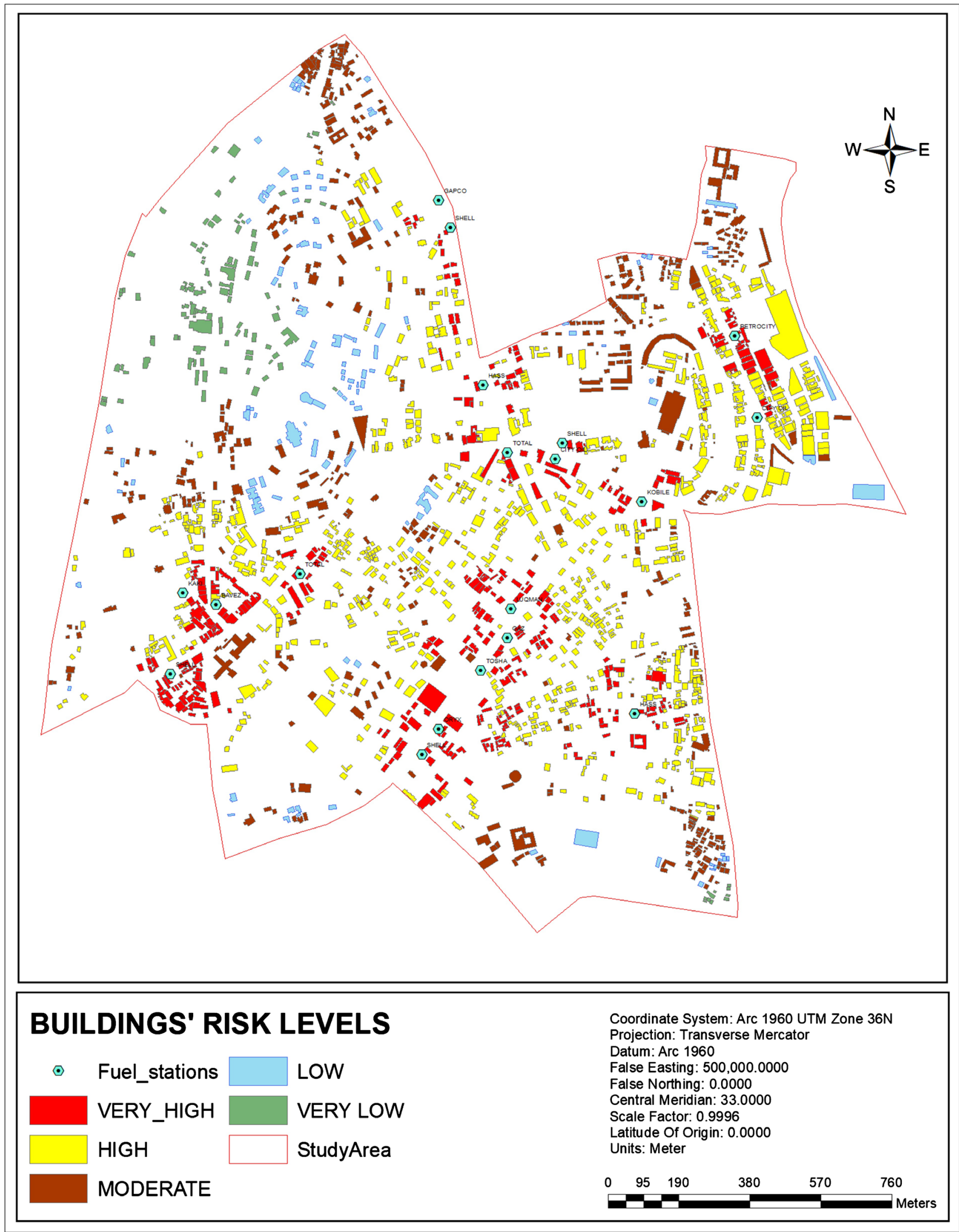

Figure 5. Fire risk map for the months of September-November. 


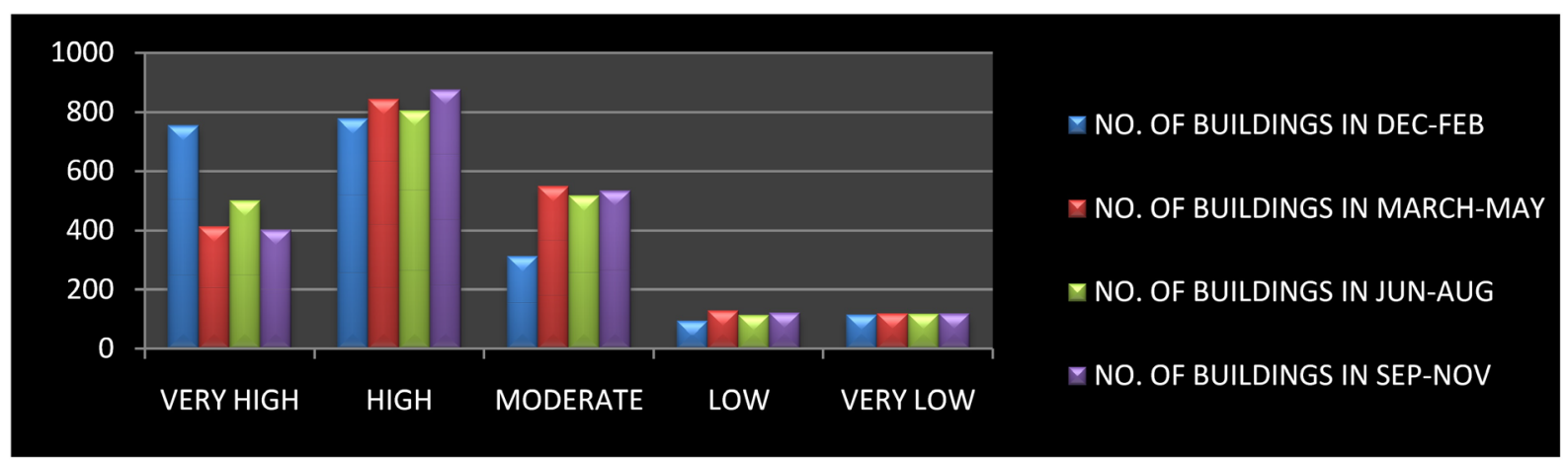

Figure 6. The different risk levels in different quarters.

Table 4. Shows suggested distances based on the influence of parameters in different risk levels.

\begin{tabular}{cc}
\hline Building Roofing Materials & Distance between buildings \\
\hline Concrete vs. concrete & $4 \mathrm{~m}$ \\
Tiles on wood vs. tiles on wood & $6 \mathrm{~m}$ \\
Iron sheets on wood vs. iron sheets on wood & $8 \mathrm{~m}$ \\
Concrete vs. tiles on wood & $5 \mathrm{~m}$ \\
Concrete vs. iron sheets on wood & $6 \mathrm{~m}$ \\
Tiles on wood vs. iron sheets on wood & $7 \mathrm{~m}$ \\
\hline
\end{tabular}

to the above suggested separation distances, they will be increased by the percentage increase in slope. According to [21], slope percent influence fire intensity in such a way that steeper slopes lead to increased rate of spread when fire is moving upslope. According to [4], the association between fire severity and slope was detected in the univariate analysis for the Big Bar complex where stations on shallow slopes were more likely to burn with moderate severity, and the probability of burning with low and high severity increased as slope increased. Hence the need to increase the suggested separation distances from one building to another with percentage increase in slope. Because of high level of development within the available land, new fuel stations should be located within a distance of $50 \mathrm{~m}$ from buildings made of concrete roof and roof tiles. But if the majority of the buildings are made of corrugated iron sheets on wood, they should be located at least $50 \mathrm{~m}$ from buildings. Buildings made of corrugated iron sheets should be located at least $50 \mathrm{~m}$ from fuel stations.

To test the suggested separation distances from one building to another, we based on a study by [22] where the spread of fire between buildings is influenced by convective heat transfer, radiative heat transfer and the percentage of window openings. He concluded that it takes 1 hour for fire spread between buildings separated by $4 \mathrm{~m}, 2$ hours for $6 \mathrm{~m}$ and 3 hours for $8 \mathrm{~m}$. It shows that the higher the distance, the longer the time taken by fire and vice versa. His distances were used to test the suggested separation distances of this study. Since he did not specify the building materials of the two buildings, we put into consideration 
that concrete roofs are more fire resistant, followed by tiled roofs and finally corrugated iron sheets.

Testing the suggested distances of buildings from fuel stations, new fuel stations should be located within a distance of $50 \mathrm{~m}$ from buildings made of concrete roof and roof tiles and at a distance of at least $50 \mathrm{~m}$ from buildings made of corrugated iron sheets. This was based on a study conducted by [23] about assessing the impact of fuel stations on their immediate surroundings based on the fact that the concentration ratio of $n$-hexane and benzene found in the air of fuel stations is different from that found in the city air. He concluded that the concentration of vapor in the air reduces with distance from the fuel stations (see Figure 7).

From the above graph, the maximum concentration of the vapor is approximately $50 \mathrm{~m}$ from the fuel station. Above $50 \mathrm{~m}$, the concentration level is minimal. Since corrugated iron sheets are easily affected by rust which can be caused by the condensation of these vapors, they are then suggested to be $50 \mathrm{~m}$ from the from fuel stations, unlike concrete roofs and tiled roofs.

\section{Conclusions}

- The fire risk from fueling stations was spatially assessed in such a way that the buildings were used to indicate the different levels of risks.

- It was shown that different parameters can be used to assess spatially the risk of fire from fueling stations.

- According to the results, it can be concluded that a building can be near a fuel station and it's less affected in case of fire outbreak because of the influence of different parameters. E.g. some buildings located within the $100 \mathrm{~m}$ buffer of the fuel stations were at a moderate level of risk.

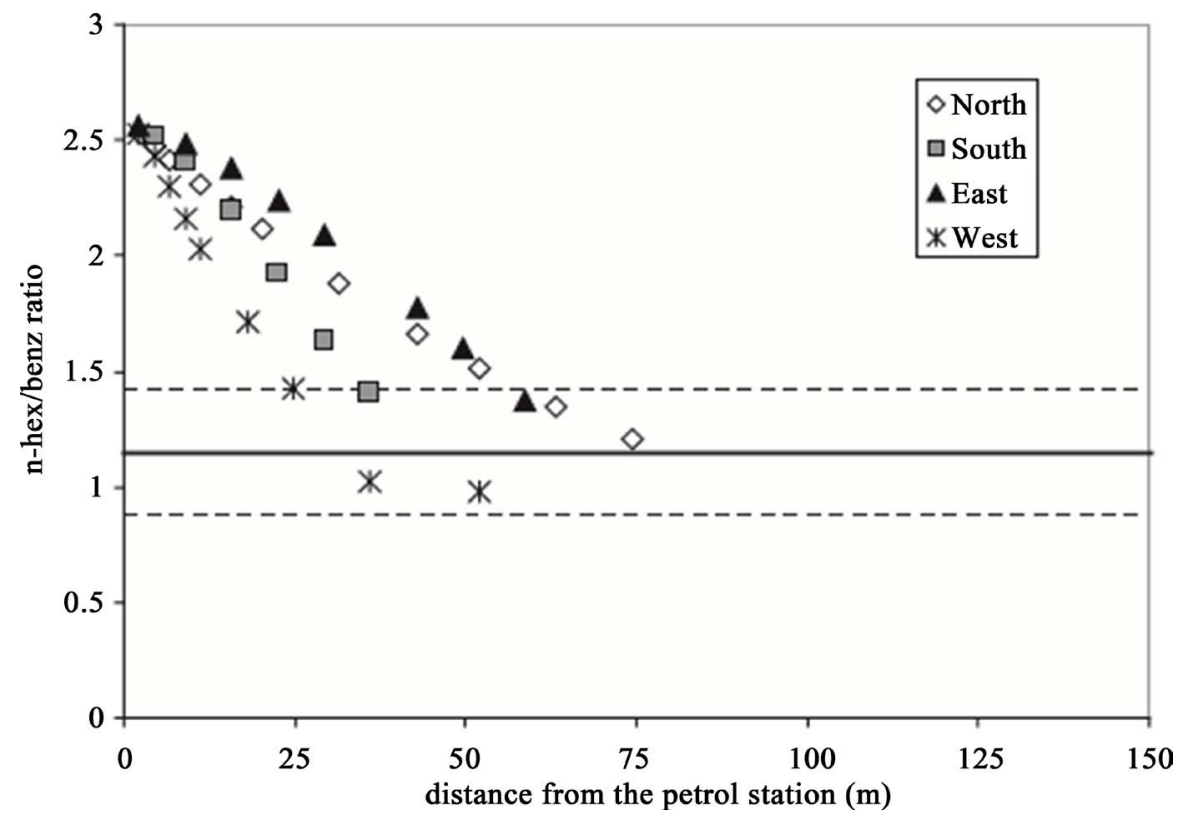

Figure 7. Movement of fuel vapors from fuel stations adopted from [22]. 
- Hence no judgment should be made that if a building is closer to a fuel station e.g. $<50 \mathrm{~m}$ it will be destroyed.

- The study also gave distances according to the different roofing materials within new buildings that should be constructed to avoid risk of fire from fuel stations.

\section{Conflicts of Interest}

The authors declare no conflicts of interest regarding the publication of this paper.

\section{References}

[1] Larok, A. (2012) How Much Oil (and Gas) Does Uganda Have, and Where Is It? Oil in Uganda, Issue 1.

https://uganda.actionaid.org/sites/uganda/files/oil_in_uganda_newsletter-pdf.pdf

[2] Bukenya (2014) Namungoona Inferno Jun. 30th. Daily Monitor.

[3] Subramaniam, C. (2004) Human Factors Influencing Safety Measures. Disaster Prevention and Management, 13, 110-116. https://doi.org/10.1108/09653560410534243

[4] Maranghides, A. and Johnsson, E.L. (2008) Residential Structure Separation Fire Experiments. U.S. Department of Commerce Technology Administration Building and Fire Research Laboratory. National Institute of Standards and Technology, Gaithersburg, MD.

[5] ATBS (2005) Static Fires at Retail Petrol Stations. Australian Government. Research Paper 2005/0028.

[6] Zhang, H.-Y. (2014) The Research about Fire Prevention of Vehicle Refuelling Stations. Procedia Engineering, 71, 385-389. https://doi.org/10.1016/j.proeng.2014.04.055

[7] ARIA (2009) Petrol Station Accidents in France 1958-2007. Ministere De L'ecologie De L'energie, Du Developmente durable et De L'amenagement Du territoire. Version 1.

[8] Mohd, S.K., Ahmad, R.S., Nooh, A.B., Mukhlis, C. and Mohtar, M. (2017) Understanding Perception of Fire Risk from Petrol Stations Workers. Journal of Engineering and Applied Science, 12, 2352-2360.

[9] Granger, K., Jones, T., Leiba, M. and Scott, G. (1999) Community Risk in Cairns: A Multi-hazard Risk Assessment. AGSO (Australian Geological Survey Organization) Cities Project, Department of Industry, Science and Resources, Australia.

[10] Meacham, B.J. (2001) Addressing Risk and Uncertainty in Performance-based Fire Protection Engineering. Fire Protection Engineering, 10, 16-25.

[11] Zhou, Y., Zhao, X.G., Zhao, J. and Chen, D. (2016) Research on Fire and Explosion Accidents of Oil Deports. The Italian Association of Chemical Engineering, 51, 163-168.

[12] Sun, X.-Q. and Luo, M.-C. (2014) Fire Risk Assessment for Super High-Rise Buildings. Procedia Engineering, 71, 492-501. https://doi.org/10.1016/j.proeng.2014.04.071

[13] Estes, B.L., Knapp, E.E., Skinner, C.N., Miller, J.D. and Preisler, H.K. (2017) Factors Influencing Fire Severity under Moderate Burning Conditions in the Klamath Mountains, Northern California, USA. Ecosphere, 8, e01794. 
https://doi.org/10.1002/ecs2.1794

[14] Khatsu, P. (2005) Urban Multi-Hazard Risk Assessment Using GIS and Remote Sensing, A Case Study of Part of Kohima Town India. International Institute for Geo-Information Science and Earth Observation, Enschede, the Netherlands.

[15] Darshan, S., Ranjith, A. and Chethan, G. (2016) A Critical Review of Fire-Resistant Structures. International Journal of Current Engineering and Scientific Research, 3, $1-5$.

[16] Sam, M.M. (2009) The Bunce Field Explosion and Fire-Lessons Learned. HAZARDS XXI Conference, Manchester Conference Centre, Manchester, United Kingdom, 10-12 November 2009.

[17] Nouri, J., Omidvari, M. and Tehrani, S. (2010) Risk Assessment and Crisis Management in Gas Stations. International Journal of Environmental Research, 4, 143-152.

[18] Sachin, K.C. and Prabin, K. (2015) Manifestation of an Analytic Hierarchy Process (AHP) Model on Fire Potential Zonation Mapping in Kathmandu Metropolitan City, Nepal. ISPRS International Journal of Geo-Information, 4, 400-417. http://www.mdpi.com/journal/ijgi/

[19] Gigović, L., et al. (2018) GIS Multi-Criteria Analysis for Identifying and Mapping Forest Fire Hazard: Nevesinje, Bosnia and Herzegovina. https://doi.org/10.17559/TV-20151230211722

[20] Saaty, T.L. (1977) A Scaling Method for Priorities in Hierarchical Structures. Journal of Mathematical Psychology, 15, 234-281. https://doi.org/10.1016/0022-2496(77)90033-5

[21] Agee, J.K. (1993) Fire Ecology of Pacific Northwest Forests. Island Press, Washington DC, $493 \mathrm{p}$.

[22] McGuire, J.K. (1959) Division of Oceanography and Meteorology: Climate and Cholera. Transactions of the New York Academy of Sciences, 21, 541-550. https://doi.org/10.1111/j.2164-0947.1959.tb01692.x

[23] Morales, I., Doval, M., Gonzalez, E.F. and Barbera, J.R. (2010) Assessing the Impact of Petrol Stations on Their Immediate Surroundings. Journal of Environmental Management, 91, 2754-2762. https://doi.org/10.1016/j.jenvman.2010.08.009 